\title{
The Prevalence of Osteoporosis in the Thrace Region of Turkey: A Community-Based Study
}

\section{Türkiye'nin Trakya Bölgesinde Osteoporoz Prevalansı: Toplum Temelli Bir Çalıșma}

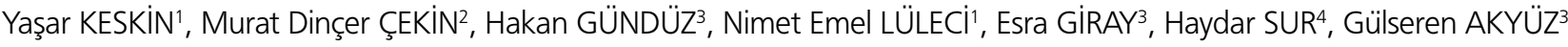 \\ ${ }^{1}$ Department of Public Health, Marmara University Faculty of Medicine, Istanbul, Turkey \\ ${ }^{2}$ Department of Health Management, Marmara University Faculty of Health Sciences, Istanbul, Turkey \\ ${ }^{3}$ Department of Physical Medicine and Rehabilitation, Marmara University Faculty of Medicine, Istanbul, Turkey \\ ${ }^{4}$ Department of Health Management, Istanbul University Faculty of Health Sciences, Istanbul, Turkey
}

\begin{abstract}
Objective: This study was planned as a community-based research study to estimate the prevalence of osteoporosis and explore related risk factors in the Thrace region of Turkey.

Material and Methods: The community-based study involved a total of 620 people, 498 women and 122 men, aged between 40 and 89 years. A questionnaire on the medical history and lifestyles of the participants was applied with a face-to-face interview. Body weight height, and arm span of each participant were measured, together with bone mineral density at the middle phalanges of the second, third, and fourth digits of the non-dominant hand using dual-energy $\mathrm{X}$-ray laser absorptiometry. Results: Age, clothing, lack of regular exercise, and giving birth to more than two children seem to contribute to osteoporosis, while high education, high economic level, tea and moderate alcohol consumption, oral contraceptive use, and hormone replacement therapy seem to retard osteoporosis. Osteoporotic patients had more fractures in the past. Height and weight were significantly lower in osteoporotic women. Conclusion: Lifestyle affects the prevalence of osteoporosis. Drinking tea and alcohol seems to be controversial with regard to osteoporosis risk. Key Words: Osteoporosis, bone density, risk factors, lifestyle
\end{abstract}

Özet

Amaç: Çalışma, Türkiye'nin Trakya bölgesinde osteoporoz prevalansını kestirmek ve ilgili risk faktörlerini ortaya çıkarmak amacıyla tasarlandı. Gereç ve Yöntemler: Toplum temelli çalışma, yaşları 40 ile 89 arasında, 498 kadın ve 122 erkekten oluşan toplam 620 kişiyi kapsadı. Çalışmaya katılanların tıbbi geçmişlerini ve yaşam tarzlarını sorgulayan bir anket yüz yüze gerçekleştirildi. Kilo, boy, kulaç uzunluğu ve Dual-Enerji X-ray lazer absorpsiyometri ile baskın olmayan elin 2, 3 ve 4.parmaklarının orta falankslarından kemik mineral yoğunluğu ölçüldü.

Bulgular: Yaş, giyinme, düzenli egzersiz yokluğu ve doğum sayısı osteoporoz ihtimalini arttırıyor görünürken iyi eğitimli olma, ekonomik seviyenin yüksekliği, çay ve hafif alkol tüketimi, doğum kontrol hapı kullanımı ve hormon replasman tedavisi osteoporozu yavaşlatıyor görünmektedir. Osteoporotik hastaların geçmişlerinde daha fazla kırık tespit edilmiştir. Osteoporotik kadınların boyu ve kilosu belirgin biçimde daha az bulunmuștur.

Sonuç: Yaşam stili osteoporoz prevalansını etkilemektedir. Çay ve alkol içmenin osteoporoz riski açısından etkisi tartışmalı görünmektedir. Anahtar Kelimeler: Osteoporoz, kemik yoğunluğu, risk faktörleri, yaşam stili 


\section{Introduction}

Osteoporosis is a progressive systemic skeletal disease characterized by compromised bone strength, predisposing one to an increased risk of fracture (1). It is seen in both females and males at a ratio of 2 to 1 . Clinical risk factors are increased age, female sex, low body mass index (BMI) $(\leq 19)$, parental history, immobilization, smoking, alcohol and caffeine-containing beverage intake, and secondary causes of osteoporosis that involve rheumatoid arthritis, hypogonadism (e.g., menopause before age 45 years, bilateral oophorectomy, chemotherapy treatment for breast cancer), inflammatory bowel disease, diabetes mellitus, thyroid dysfunction, liver disease, and medications (e.g., prolonged corticoid use, anticonvulsants, etc). Levels of exercise in childhood and adolescence are related to bone mineral density (BMD) later in life (1-3). The prevalence of osteoporosis in the United States is about 10 million, with presumably an additional 34 million people with low bone mass who remain undiagnosed $(2,4)$. Osteoporosis is known as a "silent thief," because it is usually asymptomatic until a fracture occurs. In Turkey, it has been estimated that more than 24,000 hip fractures occurred in women and men aged 50 years or more in 2010, $73 \%$ of which were in women. The majority of hip fractures in women occurred after the age of 75 years. Assuming no change in the age- and sex-specific incidence, the number of hip fractures is expected to increase to nearly 64,000 in 2035 (5).

Osteoporosis has physical, financial, and psychosocial effects on individuals and the community. It is necessary to diagnose the condition early to prevent fractures, and the current approach is based on the measurement of BMD. The gold standard BMD test, dual-energy X-ray absorptiometry (DXA), also has some disadvantages: false-negative results due to degenerative or hypertrophic changes, no differentiation between cortical and trabecular bone tissues, no standardization in different DXA machines, different reference values in each country, difficulty taking measurements in obese people, and its cost (6). Dual-energy X-ray laser absorptiometry (DXL) is an alternative that does not have these disadvantages; besides, it is portable. A new digital-type DXL, MetriScan, determines bone mineral density of the middle three digits. The Alara MetriScan phalangeal densitometer is reported to be more suitable and precise for postmenopausal women (7). There are a few hospital- and community-based surveys that have investigated the prevalence of osteoporosis in Turkey. The present study was planned as a community-based research study to estimate the prevalence of osteoporosis and related risk factors in the Thrace region of Turkey using DXL.

\section{Material and Methods}

The study area was the Thrace region outside of İstanbul and covered Edirne, Kırklareli, Tekirdağ, and the Thrace part of Çanakkale. More than 600,000 people over 40 years old live in the region. Because the literature indicates the prevalence of osteoporosis as 2\%-45\% among postmenopausal women and $0 \%-36 \%$ among men, depending on the assessed site (8), our sample needed to reach 340 women and 175 men for a $95 \%$ confidence interval (Table 1).

For each city, three primary healthcare centers-one from the city center, one from the counties, and one from the villages-were randomly selected from a list of names. People were invited to the center to participate in the survey and were included if they gave informed consent. The study continued until the sample size for each city was achieved.

A questionnaire, prepared by the researchers and consisting of 51 questions on the medical history and lifestyle of the participants, was applied with a face-to-face interview. The interview queried age; education and economic status; daily consumption of tea, coffee, cola, cigarettes, and alcohol; and clothing. According to home and automobile ownership, economic status was ranked as high, middle, or low-i.e., both, only automobile, or none. If the answer was "sometimes" in the questions related to smoking and alcohol intake, the answer was considered "yes." The women were asked about their gynecological history. The individuals were also asked if they had diabetes mellitus, fragility fractures, or a family history of fracture. Regular exercises and physical activities of individuals between age intervals (15$25,26-50$, and above 50) at home and at work were queried by asking them to determine their own maximum possible activity levels. Activities relating to each age interval were given scores of mild, moderate, heavy, and very heavy, and the total physical activity score was obtained by adding them up.

Height, weight, and arm span of the individuals were measured, and BMI was calculated by dividing the weight by height squared $\left(\mathrm{kg} / \mathrm{m}^{2}\right)$. Then, BMD was measured at the middle phalanges of the second, third, and fourth digits of the non-dominant hand by a MetriScan device (Alara Inc, USA). The MetriScan uses radiographic absorptiometry (RA) to take high-resolution

Table 1. Total population and sample

\begin{tabular}{|c|c|c|c|c|c|c|c|c|}
\hline \multirow[t]{2}{*}{ Cities } & \multicolumn{3}{|c|}{ People over 40 years old } & \multicolumn{2}{|c|}{$\%$} & \multicolumn{3}{|c|}{ Sample } \\
\hline & Women & Men & Total & Women & Men & Women & Men & Total \\
\hline Edirne & 63,796 & 72,187 & 135,983 & 22 & 23 & 75 & 40 & 115 \\
\hline Tekirdağ & 87,601 & 96,210 & 183,811 & 31.5 & 30.5 & 107 & 53 & 160 \\
\hline Çanakkale & 81,369 & 88,723 & 170,092 & 28.5 & 28.5 & 97 & 50 & 147 \\
\hline
\end{tabular}


images and estimates relative bone density of the three phalanges, comparing the intensity with a reference wedge embedded under the hand plate. In accordance with the World Health Organization's classification, those with $\mathrm{T}$ score values lower than -2.5 were accepted as having osteoporosis (9).

\section{Statistical analysis}

Percentage, Mann-Whitney U test, chi-square test, and logistic regression analysis were used to analyze the data of the study.

\section{Results}

Women were more interested in measuring their BMDs, and the study involved 498 women and 122 men (146\% higher and $70 \%$ lower, respectively, than the projected sample size) (Table 1). Of 620 people aged between 40 and 89 years (mean $54.83 \pm 10.33$ ), $19.2 \%$ had never heard the term 'osteoporosis,' and $74 \%$ could not describe it. Of those who knew osteoporosis, one-third had heard of it from a physician, one-third heard of it from a friend, and one-third heard of it from the media. Also, 23.2\% had a history of previous BMD measurements, and $13.5 \%$ had diabetes mellitus. Height and weight were significantly lower in osteoporotic women $(\mathrm{p}=0.000, \mathrm{p}=0.002)$ (Table 2$)$.

We found that the prevalence of osteoporosis in those over 40 years old was $15.1 \%$ among women and $10.7 \%$ among men, and it reached $25.7 \%$ in those over 55 years $(p=0.000)$. People who had higher education and economic level had a lower percentage of osteoporosis ( $p=0.000, p=0.010$ ). BMl did not show a significant difference between normal and osteoporotic people (Table 3).

The majority of the participants reported that they were neither cigarette smokers nor alcohol drinkers. However, more than half consumed more than 4 cups of tea per day. A minority of them consumed caffeinated drinks, like coffee or cola. People who consumed more tea and alcohol had a lower percentage of osteoporosis ( $p=0.014, p=0.038)$, and those who covered more parts of their body outside seemed to be more prone to osteoporosis $(p=0.000)$ (Table 4$)$.

One-third of the participants exercised regularly. Stratification analysis revealed a significantly higher percentage of osteoporosis among individuals who were not doing regular exercise $(p=0.015)$ and had lower total activity scores $(p=0.029$, $\mathrm{p}=0.001$ ) (Table 5).

Concerning gynecological history, there was no significant difference between normal and osteoporotic people with regard to age at menarche. Surprisingly, women who had menopause before 45 years had a significantly lower percentage of osteoporosis $(p=0.025)$. Women who had 3 or more children had a higher percentage of osteoporosis than those who had 1 or 2 children $(p=0.001)$. Oral contraceptive use was reported by $27 \%$, and hormone replacement therapy (HRT) was reported by $21 \%$. Women who had used oral contraceptives or had HRT were more likely to be protected from osteoporosis $(p=0.019$, $\mathrm{p}=0.003$ ) (Table 6). Logistic regression analysis of the gynecological history of women revealed that nulliparous women were 1.2 times more likely to develop osteoporosis versus 2.15 times
Table 2. Anthropometric data of women in the study

\begin{tabular}{lccc} 
Variables & $\begin{array}{c}\text { Normal } \\
\mathbf{x} \pm \mathbf{s}^{*}\end{array}$ & $\begin{array}{c}\text { Osteoporotic } \\
\mathbf{x} \pm \mathbf{s}^{*}\end{array}$ & $\begin{array}{c}\text { Statistical } \\
\text { analysis }\end{array}$ \\
\hline Height $(\mathrm{cm})$ & $159.12 \pm 6.07$ & $153.82 \pm 7.01$ & $\begin{array}{c}\mathrm{z}=-6.096 \\
\mathrm{p}=0.000^{*}\end{array}$ \\
Weight $(\mathrm{kg})$ & $71.56 \pm 12.12$ & $66.88 \pm 12.80$ & $\begin{array}{c}\mathrm{z}=-3.594 \\
\mathrm{p}=0.002^{*}\end{array}$ \\
$\begin{array}{l}\text { Arm span-height } \\
\text { difference }(\mathrm{cm})\end{array}$ & $3.40 \pm 3.52$ & $4.31 \pm 4.27$ & $\begin{array}{l}\mathrm{z}=-1.423 \\
\mathrm{p}=0.155\end{array}$ \\
\hline
\end{tabular}

*Arithmetic mean \pm standard deviation

${ }^{*} \mathrm{p}<0.05$ Mann-Whitney U test

Table 3. Characteristics of participants

\begin{tabular}{|c|c|c|c|c|c|}
\hline \multirow[b]{2}{*}{ Variables } & \multicolumn{2}{|c|}{ Normal } & \multicolumn{2}{|c|}{ Osteoporotic } & \multirow{2}{*}{$\begin{array}{c}\text { Statistical } \\
\text { analysis }\end{array}$} \\
\hline & $\mathbf{n}$ & $\%$ & $\mathbf{n}$ & $\%$ & \\
\hline \multicolumn{6}{|l|}{ Age } \\
\hline$\leq 55$ & 327 & 95.1 & 17 & 4.9 & $X^{2}=54.309$ \\
\hline$>55$ & 205 & 74.3 & 71 & 25.7 & $\mathrm{p}=0.000^{*}$ \\
\hline \multicolumn{6}{|l|}{ Sex } \\
\hline Female & 423 & 84.9 & 75 & 15.1 & $X^{2}=1.561$ \\
\hline Male & 109 & 89.3 & 13 & 10.7 & $p=0.212$ \\
\hline \multicolumn{6}{|c|}{ Education status } \\
\hline$<5$ years & 310 & 81.8 & 69 & 18.2 & $X^{2}=12.888$ \\
\hline$>5$ years & 222 & 92.1 & 19 & 7.9 & $\mathrm{p}=0.000^{*}$ \\
\hline \multicolumn{6}{|c|}{ Economic status } \\
\hline Low & 31 & 77.5 & 9 & 22.5 & \multirow{3}{*}{$\begin{array}{l}X^{2}=9.194 \\
p=0.010^{*}\end{array}$} \\
\hline Middle & 245 & 90.4 & 26 & 9.6 & \\
\hline High & 256 & 82.8 & 53 & 17.2 & \\
\hline \multicolumn{6}{|l|}{ BMI } \\
\hline$<25$ & 166 & 84.7 & 30 & 15.3 & \\
\hline $25-30$ & 205 & 86.9 & 31 & 13.1 & $X^{2}=0.420$ \\
\hline$>30$ & 161 & 85.6 & 27 & 14.4 & $p=0.810$ \\
\hline Total & 532 & 85.8 & 88 & 14.2 & \\
\hline
\end{tabular}

BMI: body mass index; ${ }^{*} \mathrm{p}<0.05$

for women who did not use oral contraceptives and 3.61 times for women who did not receive HRT (Table 7).

As we expected, participants who were diagnosed with osteoporosis had more fractures in the past than others $(p=0.025)$. Unexpectedly, individuals who had reported fracture in the family were not more likely to have osteoporosis or low trauma fractures as compared with individuals with a negative family history (Table 8).

\section{Discussion}

A 2007 survey using the Alara MetriScan phalangeal densitometer reported that $1 / 3$ of postmenopausal women in Turkey had osteoporosis (10). A 2009 survey that used DXA for femoral neck BMD measurements found an osteoporosis prevalence of $12.9 \%$ among women and $7.5 \%$ among men above 50 years old. At the 
Table 4. Lifestyle of participants

\begin{tabular}{|c|c|c|c|c|c|}
\hline \multirow[b]{2}{*}{ Variables } & \multicolumn{2}{|c|}{ Normal } & \multicolumn{2}{|c|}{ Osteoporotic } & \multirow{2}{*}{$\begin{array}{c}\text { Statistical } \\
\text { analysis }\end{array}$} \\
\hline & $\mathbf{n}$ & $\%$ & $\mathbf{n}$ & $\%$ & \\
\hline \multicolumn{6}{|l|}{ Tea/day } \\
\hline$\leq 3$ cups & 226 & 81.3 & 52 & 18.7 & \multirow{3}{*}{$\begin{array}{l}X^{2}=8.509 \\
p=0.014^{*}\end{array}$} \\
\hline 4-6 cups & 204 & 89.1 & 25 & 10.9 & \\
\hline$\geq 7$ cups & 102 & 90.3 & 11 & 9.7 & \\
\hline \multicolumn{6}{|l|}{ Coffee/day } \\
\hline None & 302 & 85.1 & 53 & 14.9 & \multirow{3}{*}{$\begin{array}{c}X^{2}=0.894 \\
p=0.640\end{array}$} \\
\hline 1 cup & 200 & 86.2 & 32 & 13.8 & \\
\hline$\geq 2$ cups & 30 & 90.9 & 3 & 9.1 & \\
\hline \multicolumn{6}{|c|}{ More than $\mathbf{4}$ glasses of cola } \\
\hline No & 505 & 85.6 & 85 & 14.4 & \multirow{2}{*}{$\begin{array}{l}X^{2}=0.455 \\
p=0.362\end{array}$} \\
\hline Yes & 27 & 90.0 & 3 & 10.0 & \\
\hline \multicolumn{6}{|l|}{ Smoking } \\
\hline Never & 316 & 83.2 & 64 & 16.8 & \multirow{3}{*}{$\begin{array}{l}X^{2}=5.660 \\
p=0.059\end{array}$} \\
\hline In the past & 79 & 89.8 & 9 & 10.2 & \\
\hline Now & 137 & 90.1 & 15 & 9.9 & \\
\hline \multicolumn{6}{|l|}{ Alcohol } \\
\hline No & 444 & 84.6 & 81 & 15.4 & \multirow{2}{*}{$\begin{array}{l}X^{2}=4.291 \\
p=0.038^{*}\end{array}$} \\
\hline Yes & 88 & 92.6 & 7 & 7.4 & \\
\hline \multicolumn{6}{|l|}{ Clothing } \\
\hline $\begin{array}{l}\text { Head, arms, and } \\
\text { legs open }\end{array}$ & 348 & 90.9 & 35 & 9.1 & \multirow{5}{*}{$\begin{aligned} X^{2} & =22.648 \\
p & =0.000^{*}\end{aligned}$} \\
\hline $\begin{array}{l}\text { Head open, arms } \\
\text { and legs covered }\end{array}$ & 78 & 76.5 & 24 & 23.5 & \\
\hline $\begin{array}{l}\text { Head, arms, and } \\
\text { legs covered }\end{array}$ & 92 & 79.3 & 24 & 20.7 & \\
\hline $\begin{array}{l}\text { Head, face, arms, } \\
\text { and legs overed }\end{array}$ & 14 & 73.7 & 5 & 26.3 & \\
\hline Total & 532 & 85.8 & 88 & 14.2 & \\
\hline
\end{tabular}

age of 50, the remaining lifetime probability of a hip fracture was $3.5 \%$ in men and $14.6 \%$ in women (5). Our study in the Thrace region of Turkey with the Alara MetriScan phalangeal densitometer supported what other studies revealed: age is a predisposing factor, and education level seems to be an advantage for osteoporosis (11). The percentage of osteoporosis was found to be lower among people with higher economic status. BMI did not change significantly in normal and osteoporotic people, contrary to previous findings (10).

In our study, the percentage with osteoporosis was lower among individuals who consumed more tea and alcohol, though there was no significant difference with regard to coffee consumption. Results from the Mediterranean Osteoporosis Study (MEDOS) showed that drinking tea was associated with a $30 \%$ reduction in the risk of hip fractures in both women and men over 50 years old $(12,13)$. Older women who drank tea had higher BMD mea-
Table 5. Physical activities of participants according to age interval

\begin{tabular}{|c|c|c|c|c|c|}
\hline \multirow[b]{2}{*}{ Variables } & \multicolumn{2}{|c|}{ Normal } & \multicolumn{2}{|c|}{ Osteoporotic } & \multirow{2}{*}{$\begin{array}{c}\text { Statistica } \\
\text { analysis }\end{array}$} \\
\hline & $\mathbf{n}$ & $\%$ & $\mathbf{n}$ & $\%$ & \\
\hline \multicolumn{6}{|c|}{ Regular exercise } \\
\hline Yes & 185 & 90.7 & 19 & 9.3 & $X 2=5.945$ \\
\hline No & 347 & 83.4 & 69 & 16.6 & $\mathrm{p}=0.015^{*}$ \\
\hline
\end{tabular}

Activity between $15-25$ years

$\begin{array}{lccccc}\text { Mild } & 116 & 87.2 & 17 & 12.8 & \\ \text { Moderate } & 151 & 92.1 & 13 & 7.9 & \text { X2=9.047 } \\ \text { Heavy } & 127 & 81.9 & 28 & 18.1 & \mathrm{p}=0.029^{*} \\ \text { Very heavy } & 120 & 82.2 & 26 & 17.8 & \end{array}$

\section{Activity between $26-50$ years}

$\begin{array}{lccccc}\text { Mild } & 104 & 88.1 & 14 & 11.9 & \\ \text { Moderate } & 140 & 90.3 & 15 & 9.7 & \text { X2=5.755 } \\ \text { Heavy } & 175 & 82.9 & 36 & 17.1 & \mathrm{p}=0.124 \\ \text { Very heavy } & 92 & 82.1 & 20 & 17.9 & \end{array}$

Activity above 50 years

\begin{tabular}{lccccc} 
Mild & 142 & 73.2 & 52 & 26.8 & \\
Moderate & 99 & 90.0 & 11 & 10.0 & $\times 2=15.540$ \\
Heavy & 56 & 84.8 & 10 & 15.2 & $\mathrm{p}=0.001^{*}$ \\
Very heavy & 35 & 87.5 & 5 & 12.5 & \\
\hline${ }^{*} \mathrm{p}<0.05$ & & & & &
\end{tabular}

surements than those who did not drink tea. The researchers suggested that this might be explained by the components in tea, such as phytoestrogens or fluoride. Tea contains a different pattern of nutrients (e.g., flavonoids) than coffee, which may have other potential effects on bone (14).

Multivariate analyses suggested an increase in BMD with drinking tea (15). Several studies in populations in which drinking coffee is the major source of caffeine (>80\%) showed an inverse relation between estimated caffeine intake and BMD in older women (16-20). But, in contrast to these studies, a cohort study found that drinking coffee was not a predictor of osteoporosis (21); in fact, although it was not significant, mean BMD was higher in coffee drinkers (22).

While we found no difference in osteoporosis between smokers and non-smokers, previous studies have suggested that cigarette smoking has a negative effect on BMD and osteoporotic fractures (23-27). While excessive alcohol intake negatively affects BMD (28), moderate alcohol consumption seems to have a positive effect $(21,29,30)$. Other studies, however, have failed to find such an effect for smoking and alcohol (18,21,31-33).

Covering the body seems to accelerate osteoporosis, and getting sufficient sunlight is a measure to avoid osteoporosis, a result of the study that is consistent with the literature (34).

Our study revealed a significantly lower percentage of osteoporosis among people who had physical activity and did regular 
Table 6. Gynecological history of women

\begin{tabular}{|c|c|c|c|c|c|}
\hline \multirow[b]{2}{*}{ Variables } & \multicolumn{2}{|c|}{ Normal } & \multicolumn{2}{|c|}{ Osteoporotic } & \multirow{2}{*}{$\begin{array}{c}\text { Statistical } \\
\text { analysis }\end{array}$} \\
\hline & $\mathbf{n}$ & $\%$ & $\mathbf{n}$ & $\%$ & \\
\hline \multicolumn{6}{|c|}{ Age at menarche } \\
\hline$<13$ & 76 & 88.4 & 10 & 11.6 & \multirow{3}{*}{$\begin{array}{c}x^{2}=2.252 \\
p=0.324\end{array}$} \\
\hline $13-15$ & 233 & 85.7 & 39 & 14.3 & \\
\hline$>15$ & 114 & 81.4 & 26 & 18.6 & \\
\hline \multicolumn{6}{|c|}{ Age at menopause } \\
\hline$\leq 45$ & 245 & 88.1 & 33 & 11.9 & $X^{2}=5.005$ \\
\hline$>45$ & 178 & 80.9 & 42 & 19.1 & $\mathrm{p}=0.025^{*}$ \\
\hline \multicolumn{6}{|c|}{ Number of live births } \\
\hline$\leq 2$ & 258 & 89.3 & 31 & 10.7 & $X^{2}=10.110$ \\
\hline$\geq 3$ & 165 & 78.9 & 44 & 21.1 & $\mathrm{p}=0.001$ * \\
\hline \multicolumn{6}{|c|}{ Oral contraceptive } \\
\hline Yes & 123 & 91.1 & 12 & 8.9 & $X^{2}=5.514$ \\
\hline No & 300 & 82.6 & 63 & 17.4 & $\mathrm{p}=0.019^{*}$ \\
\hline \multicolumn{6}{|c|}{ HRT utilization } \\
\hline Yes & 97 & 94.2 & 6 & 5.8 & \multirow{3}{*}{$\begin{array}{l}x^{2}=8.658 \\
p=0.003^{*}\end{array}$} \\
\hline No & 326 & 82.5 & 69 & 17.5 & \\
\hline Total & 423 & 84.9 & 75 & 15.1 & \\
\hline
\end{tabular}

Table 7. Logistic regression analysis of gynecological history of women

\begin{tabular}{lcccc} 
& $\beta$ & SE & P & OR $(95 \%$ Cl $)$ \\
\hline $\begin{array}{l}\text { Menopause-menarche } \\
\text { (years) }\end{array}$ & -0.049 & 0.025 & $0.049^{*}$ & $0.953(0.907-1.000)$ \\
No childbirth & 0.180 & 0.067 & $0.007^{*}$ & $1.197(1.050-1.366)$ \\
No oral contraceptive & 0.765 & 0.388 & $0.024^{*}$ & $2.149(1.107-4.171)$ \\
No HRT & 1.284 & 0.448 & $0.004^{*}$ & $3.610(1.501-8.684)$ \\
Constant & -2.416 & 0.913 & $0.008^{*}$ & 0.089 \\
\hline
\end{tabular}

${ }^{*} \mathrm{p}<0.05$; OR: odds ratio

Table 8. Fracture history of participants

\begin{tabular}{lcccccc} 
& \multicolumn{2}{c}{ Normal } & & \multicolumn{2}{c}{ Osteoporotic } & $\begin{array}{c}\text { Statistical } \\
\text { Vanalysis }\end{array}$ \\
\cline { 2 - 3 } Fracture & $\mathbf{n}$ & $\%$ & & $\mathbf{n}$ & $\%$ & \\
Yes & 49 & 76.6 & 15 & 23.4 & $\mathrm{X}^{2}=5.007$ \\
No & 483 & 86.9 & 73 & 13.1 & $\mathrm{p}=0.025^{*}$ \\
Family history of fracture & & & & \\
Yes & 68 & 86.1 & 11 & 13.9 & \\
No & 408 & 85.2 & 71 & 14.8 & $\mathrm{X}^{2}=0.120$ \\
No comment & 56 & 90.3 & 6 & 9.7 & $\mathrm{p}=0.942$ \\
Total & 532 & 85.8 & 88 & 14.2 & \\
\hline${ }^{*} \mathrm{p}<0.05$ & & & & &
\end{tabular}

exercise. The effect of physical activity on BMD has been reported by previously published research (35).

Studies in the past have found that HRT has a protective effect on BMD $(19,31,36)$. Similarly, in our study, postmenopausal women who received HRT were less likely to have osteoporosis. Also, oral contraceptives seemed to provide an advantage. Women who had menopause before 45 years had a significantly lower percentage of osteoporosis in our study, contrary to most of the literature. This may be due to HRT usage in these women.

Osteoporotic participants had more fractures in the past than others, as we expected. But, the participants' family histories of fracture did not contribute significantly to osteoporosis or low trauma fractures, which needs an explanation.

\section{Conclusion}

The current study revealed that osteoporosis is an important health problem in the Thrace region of Turkey, because onefourth of people are osteoporotic after 55 years of age. The prevalence is $15.1 \%$ among women and $10.7 \%$ among men over 40 years old. Promoting a healthy lifestyle through health education is a necessary measure to prevent osteoporosis.

Ethics Committee Approval: At the time the study began, project funding regulations did not mandate an Ethics Committee approval.

Informed Consent: Informed consent was obtained from each participant.

Peer-review: Externally peer-reviewed.

Author Contributions: Concept - Y.K., G.A.; Design - M.D.Ç., H.G.; Supervision - Y.K., N.E.L., E.G.; Funding - Y.K., G.A.; Materials - Y.K., G.A.; Data Collection and/or Processing - Y.K., H.S.; Analysis and/or Interpretation - M.D.Ç., H.G., N.E.L., H.S.; Literature Review - M.D.Ç., E.G.; Writer - M.D.Ç., H.G., G.A.; Critical Review - Y.K., M.D.Ç., H.G., N.E.L., E.G., H.S., G.A.

Conflict of Interest: No conflict of interest was declared by the authors.

Financial Disclosure: Funded by Marmara University Scientific Research Projects Unit.

Etik Komite Onayı: Araştırmanın başladığı tarihte, proje destek mevzuatı Etik Komite onayını şart koşmuyordu.

Hasta Onamı: Her katılımcıdan aydınlatılmış onam alındı.

Hakem değerlendirmesi: Dış bağımsız.

Yazar Katkıları: Fikir - Y.K., G.A.; Tasarım - M.D.Ç., H.G.; Denetleme - Y.K., N.E.L., E.G.; Kaynaklar - Y.K., G.A.; Malzemeler - Y.K., G.A.; Veri toplanması ve/veya işlemesi - Y.K., H.S.; Analiz ve/veya yorum - M.D.Ç., H.G., N.E.L., H.S.; Literatür taraması - M.D.Ç., E.G.; Yazıyı yazan - M.D.Ç., H.G., G.A.; Eleştirel İnceleme - Y.K., M.D.Ç., H.G., N.E.L., E.G., H.S., G.A.

Çıkar Çatışması: Yazarlar çıkar çatışması bildirmemişlerdir.

Finansal Destek: Marmara Üniversitesi Bilimsel Araştırma Projeleri Birimi tarafından desteklenmiştir. 


\section{References}

1. NIH Consensus Development Panel on Osteoporosis Prevention, Diagnosis, and Therapy. Osteoporosis prevention, diagnosis, and therapy. JAMA 2001;285:785-95.

2. Osteoporosis Overview. NIH Publication. Available from: http:// www.niams.nih.gov/Health_Info/Bone/Osteoporosis/

3. WHO Fracture Risk Assessment Tool. Available from: http://www. shef.ac.uk/FRAX/?lang=tu

4. National Osteoporosis Foundation. America's bone health: the state of osteoporosis and low bone mass in our nation. 2002, Washington, DC. Available from: http://www.nof.org

5. Tuzun S, Eskiyurt N, Akarirmak U, Saridogan M, Senocak M, Johansson $\mathrm{H}$, et al. Incidence of hip fracture and prevalence of osteoporosis in Turkey: the FRACTURK study. Osteoporos Int 2012;23:949-55. [CrossRef]

6. El Maghraoui A, Achemlal L, Bezza A. Monitoring of dual-energy X-ray absorptiometry measurement in clinical practice. J Clin Densitom 2006;9:281-6. [CrossRef]

7. Thorpe JA, Steel SA. The Alara MetriScan phalangeal densitometer: evaluation and triage thresholds. Br J Radiol 2008;81:778-83. [CrossRef]

8. Melton LJ 3rd. The prevalence of osteoporosis: gender and racial comparison. Calcif Tissue Int 2001;69:179-81. [CrossRef]

9. Kanis JA, Melton LJ 3rd, Christiansen C, Johnston CC, Khaltaev N The diagnosis of osteoporosis. J Bone Miner Res 1994;9:1137-41. [CrossRef]

10. Hamdi Kara I, Aydin S, Gemalmaz A, Aktürk Z, Yaman H, Bozdemir $\mathrm{N}$, et al. Habitual tea drinking and bone mineral density in postmenopausal Turkish women: investigation of prevalence of postmenopausal osteoporosis in Turkey (IPPOT Study). Int J Vitam Nutr Res 2007;77:389-97. [CrossRef]

11. Arslantas D, Metintas S, Unsal A, Isikli B, Kalyoncu C, Arslantas A. Prevalence of osteoporosis in middle Anatolian population using calcaneal ultrasonography method. Maturitas 2008;59:234-41. [CrossRef]

12. Johnell O, Gullberg B, Kanis JA, Allander E, Elffors L, Dequeker J, et al. Risk factors for hip fracture in European women: the MEDOS Study. Mediterranean Osteoporosis Study. J Bone Miner Res 1995;10:1802-15. [CrossRef]

13. Kanis J, Johnell O, Gullberg B, Allander E, Elffors L, Ranstam J, et al. Risk factors for hip fracture in men from southern Europe: the MEDOS study. Mediterranean Osteoporosis Study. Osteoporos Int 1999;9:45-54. [CrossRef]

14. Hegarty VM, May HM, Khaw KT. Tea drinking and bone mineral density in older women. Am J Clin Nutr 2000;71:1003-7.

15. Chen Z, Pettinger MB, Ritenbaugh $C$, LaCroix AZ, Robbins J, Caan $B$ J, et al. Habitual tea consumption and risk of osteoporosis: a prospective study in the women's health initiative observational cohort. Am J Epidemiol 2003;158:772-81. [CrossRef]

16. Yano K, Heilbrun LK, Wasnich RD, Hankin JH, Vogel JM. The relationship between diet and bone mineral content of multiple skeletal sites in elderly Japanese-American men and women living in Hawaii. Am J Clin Nutr 1985;42:877-88.
17. Harris SS, Dawson-Hughes B. Caffeine and bone loss in healthy postmenopausal women. Am J Clin Nutr 1994;60:573-8.

18. Cooper C, Atkinson EJ, Wahner HW, O'Fallon WM, Riggs BL, Judd $\mathrm{HL}$, et al. Is caffeine consumption a risk factor for osteoporosis? I Bone Miner Res 1992;7:465-71. [CrossRef]

19. Bauer DC, Browner WS, Cauley JA, Orwoll ES, Scott JC, Black DM, et al. Factors associated with appendicular bone mass in older women. Ann Intern Med 1993;118:657-65. [CrossRef]

20. Johansson C, Mellström D, Lerner U, Ostenberg T. Coffee drinking: a minor risk factor for bone loss and fractures. Age Ageing 1992;21:20-6. [CrossRef]

21. Kroger H, Tuppurainen R, Honkanen R, Alhava E, Saarikosi S. Bone mineral density and risk factors for osteoporosis: a population based study of 1600 perimenopausal women. Calcif Tissue Int 1994;55:1-7. [CrossRef]

22. Barrett-Connor E, Chang JC, Edelstein SL. Coffee-associated osteoporosis offset by daily milk consumption. The Rancho Bernardo Study. JAMA 1994;271:280-3. [CrossRef]

23. Krall EA, Dawson-Hughes B. Smoking and bone loss among postmenopausal women. J Bone Miner Res 1991;6:331-8. [CrossRef]

24. Law MR, Hackshaw AK. A meta-analysis of cigarette smoking, bone mineral density and risk of hip fracture: recognition of a major effect. BM] 1997;315:841-6. [CrossRef]

25. Slemenda CW, Hui SL, Longcope C, Johnston CC Jr. Cigarette smoking, obesity, and bone mass. J Bone Miner Res 1989;4:737-41. [CrossRef]

26. Hopper JL, Seeman E. The bone density of female twins discordant for tobacco use. N Engl J Med 1994;330:387-92. [CrossRef]

27. Hollenbach KA, Barrett-Connor E, Edelstein SL, Holbrook T. Cigarette smoking and bone mineral density in older men and women. Am J Public Health 1993;83:1265-70. [CrossRef]

28. Dalén N, Lamke B. Bone mineral losses in alcoholics. Acta Orthop Scand 1976;47:469-71. [CrossRef]

29. Holbrook T, Barrett-Connor E. A prospective study of alcohol consumption and bone mineral density. BMJ 1993;306:1506-9. [CrossRef]

30. Felson DT, Zhang Y, Hannan MT, Kannel WB, Kiel DP. Alcohol intake and bone mineral density in elderly men and women. The Framingham Study. Am J Epidemiol 1995;142:485-92.

31. Stevenson JC, Lees B, Devenport M, Cust MP, Ganger KF. Determinants of bone density in normal women: risk factors for future osteoporosis? BMJ 1989;298:924-8. [CrossRef]

32. Hu JF, Zhao XH, Chen JS, Fitzpatrick J, Barpia B, Campbell TC. Bone density and lifestyle characteristics in premenopausal and postmenopausal Chinese women. Osteoporos Int 1994;4:288-97. [CrossRef]

33. Grainge MJ, Coupland CAC, Cliffe SJ, Chilvers CED, Hosking DJ. Cigarette smoking, alcohol and caffeine consumption, and bone mineral density in postmenopausal women. Osteoporos Int 1998;8:355-63. [CrossRef]

34. Alagöl F, Shihadeh Y, Boztepe H, Tanakol R, Yarman S, Azizlerli H, et al. Sunlight exposure and vitamin $D$ deficiency in Turkish women. J Endocrinol Invest 2000;23:173-7. [CrossRef]

35. Santora AC. Role of nutrition and exercise in osteoporosis. Am I Med 1987;82:73-9. [CrossRef]

36. Mobasheri A, Shakibaei M. Osteogenetic effects of resveratrol in vitro: potential for the prevention and treatment of osteoporosis. Ann N Y Acad Sci 2013;1290:59-66. [CrossRef] 